\title{
Rethinking macroeconomic policies for development
}

DEEPAK NAYYAR*

The global economic crisis has created an opportunity to rethink macroeconomics for development. Such rethinking is both necessary and desirable. It is essential to redefine macroeconomic objectives so that the emphasis is on fostering employment creation and supporting economic growth instead of the focus on price stability alone. It is just as important to rethink macroeconomic policies which cannot simply be used for the management of inflation and the elimination of macroeconomic imbalances, since fiscal and monetary policies are powerful and versatile instruments in the pursuit of development objectives. In doing so, it is essential to the overcome the constraints embedded in orthodox economic thinking and recognize the constraints implicit in the politics of ideology and interests.

Keywords: full employment; economic growth; fiscal policy; monetary policy; pro-cyclical policies; inflation; fiscal deficit; interest rate; stabilization; adjustment.

JEL Classification: E6; E50; E52; E58; O10; O11.

\section{INTRODUCTION}

The object of this essay is to develop three propositions. First, it is both necessary and desirable to rethink macroeconomic policies for development. The global economic crisis has created an opportunity for change, which should not be missed and must be captured. Second, this is easier said than done. It is possible if and only if two shibboleths that orthodoxy has embedded in belief systems over three decades can be dispensed with. Third, even if these beliefs are set aside, there are

\footnotetext{
* Professor of Economics, Jawaharlal Nehru University, New Delhi, and Distinguished University Professor of Economics, New School for Social Research, New York. E-mail: nayyar.deepak@gmail.com. This article is based on the author's keynote presentation at the Money and Banking Conference organized by the Central Bank of Argentina, to celebrate its 75th Anniversary, at Buenos Aires, in September 2010. Submitted: September 2010; Approved October 2010.
} 
obstacles, economic and political, in the path of change. The constraints on fiscal and monetary policies embedded in orthodox economic thinking are stubborn yet surmountable, but the political constraints implicit in ideology, institutions and interests are more formidable.

\section{CRISIS AND OPPORTUNITY}

Over the past three decades, the focus of macroeconomic policies, everywhere, has become narrower with the passage of time. In industrialized countries, the traditional objectives were internal balance and external balance. ${ }^{1}$ Internal balance was defined as full employment and price stability, that would be conducive to economic growth. External balance was defined as equilibrium in the balance of payments primarily with reference to the current account. The decline of Keynesianism and the rise of monetarism in the mid-1970s led to a profound change. The conception of internal balance came to be confined to price stability, so that full employment was no longer an integral part of the objective. This was partly attributable to the belief that if the government achieves price stability, then the market will automatically achieve full employment. Since then, the notion of external balance has been progressively diluted in a world of capital account liberalization. In developing countries, the traditional concern was economic growth in the long term, subject to the constraints that inflation remained within limits of tolerance and that the current account deficit in the balance of payments remained within manageable proportions. The focus of policies shifted to macromanagement in the short term after many developing countries, to begin with in Latin America during the early 1980s, ran into debt crises or other forms of macroeconomic disequilibrium. Again, the reason put forward was that if the government succeeded in achieving price stability in the short run, all else including growth would follow. The presumption that full employment and economic growth would materialize as corollaries was belied by experience in both industrialized and developing countries. ${ }^{2}$

Macroeconomics was developed in, and for, industrialized economies. Theory and policy were both concerned with how monetary and fiscal policies should be used to attain stipulated objectives. The narrow focus led to an apparent convergence of objectives. Hence, this corpus of knowledge was sought to be used in

\footnotetext{
${ }^{1}$ The distinction between internal balance and external balance was first made by Meade (1951). These were the policy objectives of the model. There were two sets of policy instruments: income adjustments (though fiscal and monetary policies) and price adjustments (through exchange rate variations or wage flexibility).

${ }^{2}$ This argument is developed, with supporting evidence, in Stiglitz, Ocampo, Spiegel, Ffrench-Davis and Nayyar (2006).
} 
developing economies without any significant modification. Such transplantation was simply not appropriate for two reasons. ${ }^{3}$ First, the nature of relationships (between variables) and the direction of causation (what determines what) in macroeconomics are both a function of the setting or the context. The starting point for any macroeconomic analysis is the distinction between exogenous and endogenous variables or that between autonomous and induced changes. Such a distinction is essential in macroeconomic theorizing which seeks to analyze implications and prescribe policies. It is important to recognize that this distinction is derived not from the analytical structure but from the institutional setting of models. ${ }^{4}$ Second, there are systematic differences in the structural characteristics of developing economies as compared with industrialized economies. These span a wide range from differences in the constraints on output expansion, the degree of wage-price flexibility, the sources of growth, the development of financial markets, institutions and instruments, or the capacity of governments to finance their deficits, to the ability to cope with shocks and crises. ${ }^{5}$ There are also significant differences among developing countries. And even if some laws of economics are universal, the functioning of economies can be markedly different. Therefore, good economic theory and good policy analysis should recognize, rather than ignore such myriad differences. But orthodox thinking, which became dominant, simply ignored these differences.

Until the early 1980s, macroeconomic policies in developing countries were embedded in broader growth-oriented development strategies. These policies recognized the differences in structural characteristics of economies and incorporated a longer term perspective. But this approach changed for two reasons. First, macroeconomic instabilities and crises in developing countries surfaced and spread. Second, there was a shift from the Keynesian consensus on counter-cyclical demand management for full employment to the more conservative monetarist view that sought to control inflation. The control of inflation and the elimination of (internal and external) macroeconomic imbalances became the essential objectives. Orthodoxy stressed the importance of a stable macroeconomic environment. Macroeconomic policies sought to focus on stability, defined largely in terms of prices. Short term stabilization, in a narrow sense, came to be seen as the path to

\footnotetext{
${ }^{3}$ For a detailed discussion, see Nayyar (2007).

${ }^{4}$ The most important example, perhaps, is the Keynesian idea that investment is an independent (exogenous) variable to which saving adjusts as a dependent (endogenous) variable, or that exports are autonomous while imports are induced. There are other examples. In a world without capital mobility, capital account transactions in the balance of payments were induced and shaped by the balance on current account, but in a world of capital account mobility, capital account transactions are autonomous and not induced by the current account.

${ }^{5}$ These structural differences are discussed at some length elsewhere by the author (Nayyar, 2007).
} 
long term growth. This new orthodoxy prevailed as it was imposed on economies in crisis by the IMF and the World Bank and was reinforced by international financial markets. Inflation was reduced and fiscal balances were restored. But this did not contribute to higher or faster growth. Indeed, stabilization often induced procyclical macro policies that squeezed or stifled public and private investment and thereby hurt economic growth. ${ }^{6}$

There were voices of dissent. Heterodox critics questioned orthodoxy. Yet, nothing changed. However, the dominant ideology of our times has been dented, if not discredited, by the global economic crisis. And it is beginning to lose its stranglehold on thinking, at least in political processes, if not in the ivory towers of academia. There is a growing recognition that markets are no magic wand, that the invisible hand of the market is not visible because it is not there, and that markets are good servants but bad masters. It is clear that the financial crisis and the persistent recession provide an opportunity to rethink macroeconomic policies. ${ }^{7}$

Such a rethinking must begin by redefining policy objectives. In the short-term, or in crisis situations, the prime concern should not be the stability of prices alone. The stability of output and employment is just as important. In the medium-term, or in normal times, the essential objective of macroeconomic policies cannot simply be the management of inflation and the elimination of macroeconomic imbalances. It should be just as much, if not more, about fostering employment creation and supporting economic growth. The rethinking must also extend to reconsidering policy instruments. Fiscal policy cannot be reduced to a means of reducing government deficits or restoring macroeconomic balances. It is a powerful instrument in the quest for full employment and economic growth. Monetary policy cannot be reduced to a means of controlling inflation through interest rates. It is a versatile instrument where both the price and volume of credit can be most effective in the pursuit of development objectives.

In sum, it is essential to return a developmental approach to macroeconomic policies, which is based on an integration of short-term counter-cyclical fiscal and monetary policies with long term development objectives. This should shift the focus from the financial sector to the real economy, from the short-term to the long-term and from equilibrium to development. Economic growth with full employment should be the fundamental objective of macroeconomic policies. Given the differences in the quality and maturity of institutions, the framework for macroeconomic policies in developing countries, in terms of objectives, instruments or stance, would have to be different from that in industrialized economies. Macro-

\footnotetext{
${ }^{6}$ See Stiglitz, Ocampo, Spiegel, Ffrench-Davis and Nayyar (2006). See also, Nayyar (2008).

${ }^{7}$ The implications of the financial crisis and the persistent recession in the industrialized countries for the developing world are analyzed in Nayyar (2011).
} 
economic policies in the developing world also need a broader approach insofar as the nature and sources of growth are different in the two sets of countries.

\section{STUBBORN ORTHODOX BELIEFS}

Such rethinking is easier said than done, because it requires dispensing with two shibboleths that have shaped orthodox macroeconomic policies, particularly in difficult times or crisis situations: that government deficits must be reduced and that economies must accept the pain of adjustment. This belief system was dented in the response to the global economic crisis but is beginning to resurface.

Macroeconomic policy is guided by a focus on intermediate variables such as deficits in government finances. But this can be misleading if accounting frameworks are inappropriate. ${ }^{8}$ Even appropriate accounting frameworks are not enough. The reason is simple. Such measures are like a thermometer. If it shows that the body temperature is above normal, it signals that something is wrong. But a thermometer does not provide a diagnosis for a patient. Similarly, an accounting framework can never provide a complete diagnosis, let alone a prescription, for an economy.

The accounting frameworks in use for deficits in government finances are an almost perfect illustration of this problem. And the problem is compounded because different measures are used for different purposes in a manner that is far from consistent. For a meaningful analysis of policy, therefore, it is essential that the use of accounting frameworks is determined by their macroeconomic significance. ${ }^{9}$ If the objective is to measure the total borrowing needs of the government, the gross fiscal deficit is the most appropriate. If the objective is to consider the implications of a deficit in government finances for monetary expansion, as an index of inflationary pressures, the monetized deficit is the most appropriate. If the objective is to assess whether a fiscal regime is sustainable over time, the revenue deficit is the most appropriate. If the objective is to examine what governments can do, or have done, to improve the fiscal situation, the primary deficit is the most appropriate. Yet, there is an obsessive concern about deficits in government finances that borders on fetishism. It is essential to recognize the fallacies of such deficit fetishism. ${ }^{10}$

Orthodoxy believes that reducing gross fiscal deficits is both necessary and

\footnotetext{
${ }^{8}$ See Nayyar (2008). See also, Stiglitz, Ocampo, Spiegel, Ffrench-Davis and Nayyar (2006).

${ }^{9}$ For an analysis of the different concepts of government deficits and their macroeconomic significance, see Nayyar (2008).

${ }^{10}$ For a detailed discussion on the problems with such deficit fetishism, whether fiscal deficits or monetized deficits, see Nayyar (2008).
} 
sufficient for the macroeconomic adjustment. This is a myth. The size of the fiscal deficit, or the amount of government borrowing, is the symptom and not the disease. And there is nothing in macroeconomics which stipulates an optimum level to which the fiscal deficit must be reduced as a proportion of GDP. Indeed, it is possible that a fiscal deficit at $6 \%$ of GDP is sustainable in one situation while a fiscal deficit at $4 \%$ of GDP is not sustainable in another situation. The real issue is the allocation and end-use of government expenditure in relation to the cost of borrowing by the government. Thus, government borrowing is always sustainable if it is used to finance investment and if the rate of return on such investment is greater than the interest rate payable.

In an ideal world, there should be a revenue surplus large enough to finance capital expenditure on the social sectors, as also on defence, where there are no immediate or tangible returns. This would ensure that borrowing is used only to finance investment expenditure which yields a future income flow to the exchequer. So long as that income flow is greater than the burden of servicing the accumulated debt, government borrowing remains sustainable. In the real world, however, government borrowing is sometimes used, at least in part, to support consumption expenditure. In these circumstances, the rate of return on investment, financed by the remainder of the borrowing cannot be high enough to meet the burden of servicing the entire debt. This problem is often compounded by orthodox economic policies which raise the cost of government borrowing. For one, governments are forced to cut back sharply on borrowing at low interest rates from the central bank so as to reduce monetary expansion. For another, financial deregulation means that governments have to borrow at a significantly higher cost, from the commercial bank system and the domestic capital market, as interest rates on government securities are raised to market levels.

There is a similar fetishism about monetized deficits. It serves little purpose to eliminate the monetized deficits for fear of inflation if the government continues to borrow as much from elsewhere, instead of the central bank, but at a much higher cost. There are other important macroeconomic consequences of such monetarism. For one, it makes public debt much less manageable and reduces fiscal flexibility for governments as interest payments pre-empt a much larger proportion of government expenditure. For another, high interest rates, which may not dampen government borrowing in the short run if not in the medium-term, crowd-out private investment, as rates of return on borrowed capital used to finance investment need to be much higher.

The other shibboleth also dies hard. For economies in crisis, orthodoxy believes that governments should not attempt to attain full employment. Instead, governments are urged to accept the pain of adjustment, in the form of lower output today, for a higher output tomorrow. This recommendation conforms to the strong spring analogy: the harder you push the spring down, the greater the 
force with which it bounces back. But a weak spring might be a more appropriate analogy for the economy, for when it is pushed too hard, it may simply remain there if its restorative forces are destroyed. These are mere analogies but there is evidence in support of the latter. ${ }^{11}$

In developing countries, under normal circumstances, there already exists a pro-cyclical pattern to macroeconomic policies. ${ }^{12}$ This is particularly true of fiscal policy. During downswings of the business cycle, as the economy slows down, tax revenues fall, or do not rise as much as expected. The ability of the government to service public debt diminishes. The interest rate on government borrowing rises. And governments find it not only more expensive but also more difficult to borrow in order to finance expenditure. During upswings of the business cycle, the opposite happens. Government revenues recover. So does government expenditure. And governments have more access to cheaper credit.

The social costs of pro-cyclical fiscal policies are high. In downturns, cuts in public expenditure squeeze investment in infrastructure and reduce allocations for social sectors, which can only dampen growth in the long-term. In upturns, readily available finances may be used for investments that yield low returns or even for unproductive consumption expenditure. In general, stop-go cycles are bound to reduce the efficiency of government spending. Yet, there are strong, embedded, incentives or disincentives for governments to adopt pro-cyclical fiscal policies. In a downturn, therefore, such pro-cyclical policies can only accentuate difficulties in the short-run and dampen growth in the medium-term.

The probability of such outcomes increases with orthodox stabilization and adjustment programmes, which advocate pro-cyclical macroeconomic policies: a restrictive fiscal policy and a tight monetary policy. This is just the opposite of anti-cyclical macroeconomic policies adopted as a rule by governments in industrialized countries. It is also counter-intuitive in so far as it is the opposite of what students of macroeconomics learn across the world. As a result, growth is dampened, if not stifled. ${ }^{13}$

In the aftermath of the global economic crisis, the response of most developing countries, contrary to the orthodox belief system, was to adopt counter-cyclical policies in the form of a fiscal stimulus or monetary easing or both. There were three factors that made this possible. First, the response of the industrialized countries was clear in the form of expansionary macroeconomic policies. Second, there was an international effort, through the G-20, to coordinate macroeconomic policies across countries. Third, much of the developing world, particularly the

\footnotetext{
${ }^{11}$ See Ben-David and Papell (1998) and Lutz (1999).

${ }^{12}$ For a detailed discussion, see Ocampo (2003).

${ }^{13}$ See Easterly, Islam and Stiglitz (2001).
} 
emerging economies, witnessed rapid economic growth combined with macroeconomic balances in the period before the crisis. In the process, obsessive concerns about governments deficits were also given up for some time. However, even as the Great Recession persists, the shibboleths have surfaced once again. There are some exceptions, but the stimulus is coming to an end almost everywhere and the process of reversing the stimulus has begun in several countries. The message from the G-20 is growth-friendly fiscal consolidation, which represents a return to orthodoxy through the back door. Following such advice would almost certainly be counterproductive at this juncture. ${ }^{14}$ It is essential for developing countries to resist this temptation and use the window of opportunity provided by the crisis to reinvent macroeconomic policies for development.

\section{OBSTACLES TO CHANGE}

It is bound to be said that governments in developing countries do not have much fiscal flexibility in either revenue or expenditure. Tax revenues are based less on direct taxes and more on indirect taxes. The base for taxation is not broad enough. Tax compliance is low, which is attributable to tax avoidance and tax evasion. Thus, governments find it very difficult to increase their income through tax revenues. Orthodoxy does not help matters. For, typically, tax rates are lowered without any systematic effort to improve compliance or broaden the base for taxation..$^{15}$ In the sphere of expenditure, governments find it difficult to cut consumption expenditure, so that the axe falls on public investment, which constrains growth, and on social sectors, which hurts the poor. But there is policy space which must be used and not given up. And things change for the better, through a cumulative causation, in the process of development. Public investment develops infrastructure and crowds-in private investment, both of which are conducive to growth, while expenditure on social sectors, education and health, is more investment than consumption, which can raise productivity. Government expenditure has multiplier effects that also creates revenue through buoyancy. As institutions develop and development accelerates, fiscal flexibility increases.

\footnotetext{
${ }^{14}$ In the European Union, decisions to sharply reduce fiscal deficits are in the process of implementation. It is no surprise in economies such as Greece and Ireland that are in a crisis. But the process has also begun in economies such as Germany and the United Kingdom. This change in policy stance, somewhat premature, is bound to inflict social costs on the countries and dent the prospects of recovery in the world economy. For that reason, the mounting pressure in some industrialized countries to return to business-as-usual in macroeconomic policies must also be resisted. For a discussion, see Nayyar (2011).

${ }^{15}$ The Laffer Curve belief system is not the only culprit. Tax revenues, as a proportion of GDP, may also stagnate, if not decline, as import tariffs are systematically reduced in the process of import liberalization, which is an integral part of economic reform programmes.
} 
Monetary policy in developing countries also has limits. Money markets are often segmented, if not underdeveloped. Effects of monetary policy are more narrowly directed. Its effectiveness is lower. Open market operations are obviously a limited option in thin markets. Experience shows that beyond a point higher interest rates do not combat inflation just as lowering interest rates does not stimulate investment. Interest rates are a strategic instrument to influence allocation of scarce investible resources. ${ }^{16}$ And the volume of credit could be more effective than the price of credit as an instrument of monetary policy. But the deregulation of domestic financial sectors and capital account liberalization, taken together, have reduced the space for monetary policy. This needs correction. Monetary policy should not be narrow in its objectives (managing inflation alone) and as an instrument (just interest rates). In fact, there is need to create space for monetary policy in the pursuit of development objectives. As financial markets develop, institutions evolve and instruments diversify, monetary policy can become more effective in terms of range and reach.

It is also important to recognize the somewhat different macroeconomic implications of the interaction between fiscal and monetary policy in developing countries. ${ }^{17}$ For example, the monetary impact of fiscal policy is perhaps greater in developing countries because a much larger proportion of the fiscal deficit is financed by borrowing from the central bank. In a shallow capital market, the alternatives are few and far between. And, in developing countries, borrowing from the central bank is the principal source of reserve money which makes it the most important determinant of monetary expansion. This is no longer the case in most Latin American economies, but remains the reality in most other developing countries. Similarly, the fiscal impact of monetary policy is perhaps greater in developing countries, because, in situations where public debt is large as a proportion of GDP and interest payments on these debts are large as a proportion of government expenditure, even modest changes in interest rates exercise a strong influence on fiscal flexibility.

In a changed international context, it is also important to recognize that countries which are integrated into the world financial system are constrained in using an autonomous management of demand to maintain levels of output and employment. Expansionary fiscal and monetary policies - large government deficits to stimulate aggregate demand or low interest rates to encourage domestic investment

\footnotetext{
${ }^{16}$ The striking examples of such a strategic use of interest rates are the East Asian countries, particularly Japan and Korea. See Wade (1990) and Chang (1994). In this context, it is worth noting that the deregulation of domestic financial markets in developing countries is bound to limit the use of the structure of interest rates, say a differentiation between short-term rates and long-term rates, as a means of influencing the allocation of scarce resources.
}

${ }^{17}$ For a discussion, see Nayyar (2007). 
- can no longer be used, as easily as in the past, because of an overwhelming fear that such measures could lead to speculative capital flight and a run on the national currency. The problem exists everywhere. But it is far more acute in developing countries. ${ }^{18}$

There are important lessons to be learnt from the experience of financial deregulation and capital account liberalization, in both industrialized countries and developing countries, about what should not be done. ${ }^{19}$ It is clearly essential to learn that financial deregulation, such as doing away with the distinction between banking and non-banking financial intermediaries, is fraught with risk. At the same time, in thinking of integrating with international financial markets, it is clear that it would be wise to hasten slowly with capital account liberalization. For the same reason, it would be unwise to rely on portfolio investment inflows to finance current account deficits because portfolio investment represents the intersection of two somewhat thin, very unstable, markets in developing countries: namely stock exchange markets, and foreign exchange markets. Indeed, wherever countries have moved to capital account liberalization, the option of introducing capital account controls must be retained. ${ }^{20}$

Macroeconomic policies are neither formulated nor implemented in a vacuum. It is, therefore, important to recognize the significance of the political context. What governments can or cannot do in the sphere of macroeconomic policies is also shaped in the realm of politics. It is an outcome of the ideology, the institutions and the interests that reinforce orthodox theory and practice.

Ideology: The gathering momentum of globalization, associated with an internationalization of financial markets, led to the formulation of a rationale for orthodox macroeconomic policies that is almost prescriptive. The objectives of price stability and fiscal balance became sacrosanct, which defined the role of monetary policy and fiscal policy in the narrowest possible sense. Slowly but surely, this orthodoxy was embedded in the belief systems of individuals, who influenced policy and shaped opinion, in politics and government. In this process, intellectuals from the world of academia provided the rationale and editors or columnists from the world of media provided the voice. It is no surprise that the orthodox belief system was transformed into a virtual ideology.

Institutions: The ideology is not abstract. It is in the logic of international financial markets, where price stability is almost an article of faith, high interest rates ensure profitability and strong exchange rates impart confidence. Orthodox mac-

\footnotetext{
${ }^{18}$ See Nayyar (2003).

${ }^{19}$ For an analysis of the risks associated with capital market liberalization and the alternative policy options available for macroeconomic management, see Stiglitz and Ocampo (2008).

20 The propositions about capital account liberalization and integration into international financial markets, set out briefly in this paragraph, are discussed in Nayyar (2002).
} 
roeconomic policies are simply a means to these ends. The same worldview came to be adopted by multilateral financial institutions, in particular, the IMF and the World Bank, which exercised enormous influence on policies of economies in crisis. It was only natural that this thinking spread to national institutions. The advocacy may have come from domestic financial sectors, but the policies were formulated by finance ministries while the practices were adopted by central banks.

Interests: Governments in developing countries find it very difficult to increase their income through tax revenues, because important political constituencies with a voice have the capacity not only to evade or avoid taxes but also to resist taxes. In contrast, governments in developing countries find it somewhat less difficult to decrease their expenditure, although there are asymmetries. It is easier to cut investment expenditure than to cut consumption expenditure, just as it is easier to reduce public expenditure on social sectors where the economic constituencies are not as organized as elsewhere and the consequences are discernible only after a time lag. There is a similar intersection of economics and politics in the sphere of monetary policy. ${ }^{21}$ The orthodox view does recognize this but the recognition is limited to the macroeconomic significance of monetized deficits and the independence of central banks. ${ }^{22}$ This understanding and characterisation is much too narrow. Clearly, the dominance of one institution over another could be dangerous, for it takes away checks and balances. But autonomy or independence is not the answer. Macroeconomic policies for development require partnership and coordination. In any case, there is more to the political economy of monetary policy. Constraints embedded in political economy reduce degrees of freedom in the use of interest rates. Property-owning democracies with extensive rentier interests, in developing countries, almost as much as in industrial societies, prefer higher interest rates not only because of higher income from financial assets but also because a wider middle class fears that inflation might erode the real value of their accumulated savings. In developing countries that have carried out capital account liberalization, sources of foreign capital inflows also prefer higher interest rates and lower inflation rates. It is not surprising, then, that any lowering of interest rates is resisted by an emerging rentier class in domestic financial markets which has a political voice, just as any lowering of interest rates is constrained by an integration into international financial markets which also become significant political constituencies for finance ministers.

\footnotetext{
${ }^{21}$ For a more detailed discussion, see Nayyar (2008).

${ }^{22}$ See, for example, Alesina and Summers (1993).
} 


\section{CONCLUSION}

There are some obvious conclusions that emerge from the preceding discussion. It is essential to redefine macroeconomic objectives so that the emphasis is on fostering employment creation and supporting economic growth instead of the focus on price stability alone. It is just as important to rethink macroeconomic policies which cannot simply be used for the management of inflation and the elimination of macroeconomic imbalances, since fiscal and monetary policies are powerful and versatile instruments in the pursuit of development objectives. It is sensible to exercise restraint in the deregulation of domestic financial sectors. It is prudent to hasten slowly with capital account liberalization, or retain the option of introducing capital controls. It is necessary to stay prudent in macro-management so that there is some freedom to introduce counter-cyclical macroeconomic policies. In doing this, it is essential to the overcome the constraints embedded in orthodox economic thinking and recognize the constraints implicit in the politics of ideology and interests.

\section{REFERENCES}

ALESINA, Alberto and Lawrence SUMMERS (1993). 'Central Bank Independence and Macroeconomic Performance: Some Comparative Evidence', Journal of Money, Credit and Banking, Vol. 25 No. 22, 1993, pp. 151-162.

BEN-DAVID, Dan and David PAPELL (1998). 'Slowdowns and Meltdowns: Post-War Growth Evidence from 74 Countries', Review of Economics and Statistics, Vol. 80, November, pp. 561-571.

CHANG, Ha-Joon (1994). The Political Economy of Industrial Policy, Macmillan, London.

EASTERLY, William, Roumeen ISLAM and Joseph STIGLITZ (2001). 'Shaken and Stirred: Explaining Growth Volatility', Annual Bank Conference on Development Economics 2001, World Bank, Washington DC, pp. 191-212.

LUTZ, G. Matthias (1999). 'Unit Roots versus Segmented Trends in Developing Countries Output Series', Applied Economic Letters, No. 6, pp. 181-184.

MEADE, James (1951). Theory of International Economic Policy: The Balance of Payments, Oxford University Press, Oxford.

NAYYAR, Deepak (2002). 'Capital Controls and the World Financial Authority: What Can We Learn from the Indian Experience?' in J. Eatwell and L. Taylor eds. International Capital Markets: Systems in Transition, Oxford University Press, New York.

NAYYAR, Deepak (2003). 'Globalization and Development Strategies', in J. Toye (ed.) Trade and Development: New Directions for the Twenty-first Century, Edward Elgar, Cheltenham.

NAYYAR, Deepak (2007). 'Macroeconomics in Developing Countries', Banca Nazionale del Lavoro Quarterly Review, Vol. LIX, No. 242, September, pp. 249-269.

NAYYAR, Deepak (2008). 'Macroeconomics of Structural Adjustment and Public Finance in Developing Countries: A Heterodox Perspective', International Journal of Development Issues, Vol. 7, No. 1, June, pp. 4-28. 
NAYYAR, Deepak (2011). 'The Financial Crisis, the Great Recession and the Developing World', Global Policy, Vol. 2, Issue 1, January, pp. 20-32.

OCAMPO, Jose Antonio (2003). 'Developing Countries Anti-Cyclical Policies in a Globalized World', in Amitava Dutt and Jaime Ros (eds.) Development Economics and Structuralist Macroeconomics: Essays in Honour of Lance Taylor, Edward Elgar, Cheltenham.

STIGLITZ, Joseph, Jose Antonio OCAMPO, Shari SPIEGEL, Ricardo FFRENCH-DAVIS and Deepak NAYYAR (2006). Stbility with Growth: Macroeconomics, Liberalization and Development, Oxford University Press, Oxford.

STIGLITZ, Joseph and Jose Antonio OCAMPO (2008). Capital Market Liberalization and Development, Oxford University Press, Oxford.

WADE, Robert (1990). Governing the Market: Economic Theory and the Role of Government in East Asian Industrialization, Princeton University Press, Princeton. 